\title{
Use of habitats by non-volant small mammals in Cerrado in Central Brazil
}

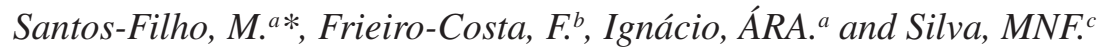 \\ aDepartamento de Ciências Biológicas, Universidade do Estado de Mato Grosso - UNEMAT, \\ CEP 78200-000, Cáceres, MT, Brazil \\ bDepartamento de Biologia, Centro Universitário de Lavras - UNILAVRAS, Lavras, MG, Brazil \\ 'Instituto Nacional de Pesquisas da Amazônia - INPA, CP 478, CEP 69083-000, Manaus, AM, Brazil \\ *e-mail: msantosfilho@gmail.com \\ Received November 28, 2011 - Accepted February 13, 2012 - Distributed November 30, 2012
}

(With 9 figures)

\begin{abstract}
Non-volant small mammals are organisms capable of yielding precise information on richness, abundance and species composition variations related to the use of habitats. The aim of this research was to compare these variations in Cerrado sensu stricto, Palm Forest, Gallery Forest and Rocky Field. From May 1999 to February 2000, we surveyed non-volant small mammals (hence small mammals) in Serra das Araras Ecological Station. We captured 218 individuals and recaptured 62 individuals, belonging to $21 \mathrm{taxa}, 13$ rodents and eight marsupials, in a total of 13200 trap-nights. Capture success was $1.7 \%$. We observed higher richness of small mammals in forested areas (Gallery Forest and Palm Forest) than in open areas (Rocky Field and Cerrado sensu stricto). The Palm Forest had the highest richness of marsupials, possibly due to the quality of a specific niche. The Rocky Field had the smallest richness, but with very high abundance of few species, mainly Thrichomys pachyurus and Monodelphis domestica. Forest habitats had similar species composition. The open habitats, Cerrado sensu stricto and Rocky Field, had a distinct species composition between them, and also when compared to forested areas. Different species are exclusive or showed preference for specific habitats. The protection of horizontally heterogeneous biomes, such as Cerrado, has a fundamental importance to the maintenance of the regional diversity of the small mammal community of Central Brazil.
\end{abstract}

Keywords: Cerrado, Ecological Station, Serra das Araras, ecology of mammals.

\section{Uso de habtats por pequenos mamíferos não-voadores no Cerrado do Brasil Central}

\section{Resumo}

Pequenos mamíferos não voadores são organismos que permitem observações precisas sobre diferenças nos aspectos de riqueza, abundância, composição e uso de habitats. Com a finalidade de investigar a existência dessas diferenças entre Cerrado sensu stricto, Mata de Palmeiras Babaçu, Mata de Galeria e Campo Rupestre, realizaram-se, no período de maio de 1999 a fevereiro de 2000, levantamentos de pequenos mamíferos não voadores na Estação Ecológica Serra das Araras. Houve a captura de 218 indivíduos e 62 recapturas, pertencentes a 21 táxons, sendo 13 roedores e 8 marsupiais, em um total de 13.200 armadilhas $\times$ noite. O sucesso total de captura foi de $1,7 \%$. A riqueza total de pequenos mamíferos foi maior nas áreas de matas (Mata de Galeria e Mata de Palmeiras Babaçu) do que nas áreas abertas (Campo Rupestre e Cerrado sensu stricto). A Mata de Palmeiras Babaçu foi a que apresentou a maior riqueza de marsupiais, possivelmente em virtude da qualidade de nicho específico. O Campo Rupestre apresentou menor riqueza, porém com abundância relativa muito alta de algumas espécies, principalmente Thrichomys pachyurus e Monodelphis domestica. Habitats florestados apresentaram similaridade em composição de espécies de pequenos mamíferos. Os habitats abertos Cerrado sensu stricto e Campo Rupestre foram distintos quanto à composição de espécies quando comparados entre si e com áreas florestadas. Diferentes espécies são exclusivas ou têm preferência por habitats específicos do mosaico fitofisionômico que forma o bioma Cerrado. A proteção de ambientaes horizontalmente heterogêneos, como é o caso do Cerrado, é de fundamental importância para manter a diversidade regional do centro-oeste brasileiro.

Palavras-chave: Cerrado, Estação Ecológica, Serra das Araras, ecologia de mamíferos. 


\section{Introduction}

The Cerrado biome lies on two million $\mathrm{km}^{2}$ of Central Brazil, it has a complex ecological formation, varying from open areas (savannas) to forests (gallery forest). It is the second largest Brazilian biome, bordering other vast biomes, such as the Amazon, the Atlantic forest, the Caatinga and the Chaco (Eiten, 1972). The Cerrado has been mainly replaced by mechanised agriculture and cattle ranches, because of its natural propensity to commodity production due to topographic characteristics. At current rates of deforestation, Cerrado will disappear in 2030 (Machado et al. 2004). The situation becomes more alarming knowing that very little is known about Cerrado's fauna, especially small mammals.

Cerrado's phyto-physiognomic variations offer great conditions to study the use of habitats. However, differential use of habitats cannot be a unique variable to measure niche overlapping and species competition. According to Mares et al. (1986), habitat is only one of many dimensions to be considered when studying interactions of sympatric species. Breeding strategies, activity patterns and other factors are part of n-dimensions of niche hyperspace to be considered.

Studies conducted in areas of Cerrado have shown that some species of small mammals have a strong preference for specific habitat types (Alho et al., 1986; Mares et al., 1986; Fonseca and Redford, 1984; Ribeiro and Marinho-Filho, 2005). Most studies about small mammals in Cerrado areas were conducted in the Brazilian Federal District by Alho (1981, 1993); Fonseca and Redford (1984); Alho et al. (1986); Mares et al. (1986); Lacher et al. (1989); Mares and Ernest (1995). Vieira and Palma (2005) compared the community structure of small mammals between different phytophysiognomies of Cerrado, however most of the research is restricted to rapid surveys and species checklists. In the State of Mato Grosso, ecological studies on small mammal communities are relatively few, and conducted between 1940s and 1970s (Vieira, 1945; Pine et al., 1970). More recent studies include Bonvicino et al. (1996) in Araguaia basin (in Cerrado), Lacher and Alho (1989) in Pantanal, and Lacher and Alho (2001) in Manso hydroelectric, in Chapada dos Guimarães (Cerrado). In addition, ecological studies about the effects of forest fragmentation on small mammal communities in southwestern Mato Grosso were conducted by Santos-Filho et al. (2008a, b).

The main aim of this study was to research the differences on richness, abundance and composition of small mammals living in distinct Cerrado's phyto-physiognomies: Cerrado sensu stricto, palm forests, gallery forests and rocky fields in Serra das Araras Ecological Station, Mato Grosso, Brazil.

\section{Study Area}

This research was conducted in Serra das Araras Ecological Station (EESA) in Porto Estrela, MT. The EESA has 28,700 ha, including a part of six hills: Camarinha, Bocaina, Três Ribeirões, Sabão Grande, Tombador and Pindeiwar (Brasil, 1997). EESA lies between latitudes $15^{\circ}$ $27^{\prime} \mathrm{S}$ and $15^{\circ} 48^{\prime} \mathrm{S}$ and longitudes $57^{\circ} 03^{\prime} \mathrm{W}$ and $57^{\circ}$ $19^{\prime} \mathrm{W}$, with heights varying from 300 to $800 \mathrm{~m}$ (Figure 1), with $50 \mathrm{~km}$ of length and $8 \mathrm{~km}$ of width (Brasil, 1979).

\section{Material and Methods}

Rodents and marsupials were systematically sampled along diurnal and nocturnal transects, from May 1999 to February 2000, in four focal habitats: Gallery Forest (GF), Palm Forest (PF), Rocky Field (RF) e Cerrado sensu stricto $(\mathrm{CE})$.

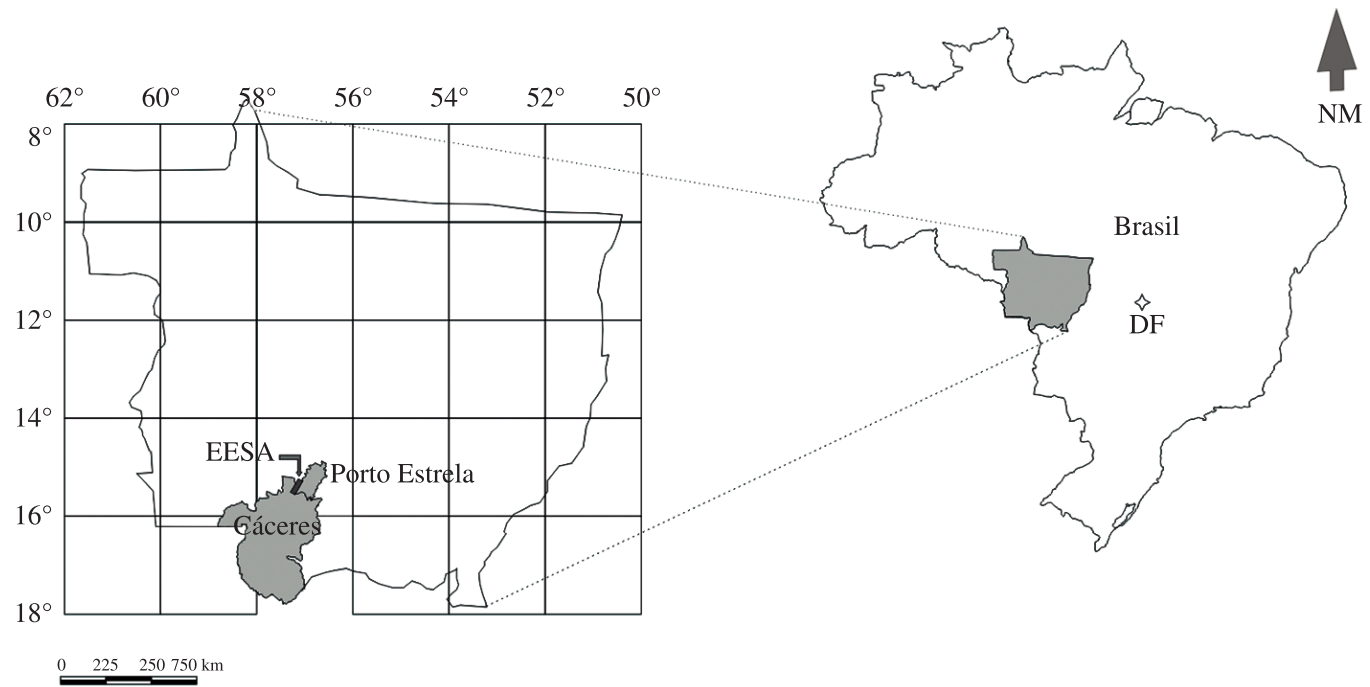

Figure 1. Location of Serra das Araras Ecological Station (EESA) in State of Mato Grosso, Brazil. 
Sampling systems in each habitat were formed by three parallel 400-m transects, $50 \mathrm{~m}$ apart (first transect to second, and second to third). Each transect had 40 sampling points apart $10 \mathrm{~m}$ along of each transect. In GF and PF, each one of the first two transects had one trap, sherman $(80 \mathrm{~mm} \times 90 \mathrm{~mm} \times 230 \mathrm{~mm})$ or tomahawk $(145 \mathrm{~mm} \times 145 \mathrm{~mm} \times 410 \mathrm{~mm})$, alternately on the ground or on tree branches at 2-m height (palm trunks and lianas were also used). Along the third transect, from the first to the twentieth point, shermans were used at high places and tomahawks on the floor; from the twenty-first point onwards, the position was inverted. In CE and RF, all traps were on the ground because of the low vegetation height and low vertical complexity; at each point one sherman or one tomahawk were used, alternately. Banana and peanut-butter were used as bait. The traps were checked for 10 days every night.

The first 10 individuals captured were sent to the mammalian collection at the State University of Mato Grosso (UNEMAT), Cáceres, MT, Brazil, and at the National Institute of Research of Amazon (INPA), Manaus, AM, Brazil. When more than ten individuals of the same species were collected, remaining individuals were marked with sequential earrings, measured and released at the same sampling point where they were captured.

\section{Results}

\subsection{Small mammals samples}

Two hundred and eighteen individuals were captured, from 21 taxa: 13 rodents and eight belonging to the order Didelphimorphia (Table 1). The sampling effort was 13,200 trap-night: 3,600 in GF; 3,600 in PF; 3,600 in CE and 2,400 in Rocky Field. The total capture success was $1.7 \%$. From 280 captures, 62 were recaptures in RF (see Table 2).

The species more frequently captured in RF was Thrichomys pachyurus, with 85 captures and 51 recaptures (representing $48.57 \%$ from the total of captures/recaptures). Monodelphis domestica was the second most captured taxon (17 captures and 11 re-captures), representing 9.96\% from the total. Both together represent more than half of the captures and recaptures $(58.53 \%)$ in RF.

The total richness of small mammals in GF and PF was ten species in each habitat, with six species inhabiting both habitats and only two species found in CE and/or

Table 1. Small mammal species richness and abundance captured with traps during dry and wet season, in Serra das Araras Ecological Station, Mato Grosso.

\begin{tabular}{|c|c|c|c|c|c|c|c|c|c|c|c|}
\hline \multirow{3}{*}{ Taxa } & \multicolumn{6}{|c|}{ Dry Season } & \multicolumn{5}{|c|}{ Wet Season } \\
\hline & May & June & July & Aug. & Sept. & Oct. & Nov. & Dec. & Jan. & Jan. & Jan. \\
\hline & GF1 & RF1 & PF1 & CE1 & GF2 & PF2 & RF2 & CE2 & PF3 & CE3 & GF3 \\
\hline \multicolumn{12}{|l|}{ Rodentia } \\
\hline Hylaeamys megacephalus & 0 & 0 & 0 & 0 & 0 & 0 & 0 & 0 & 0 & 0 & 1 \\
\hline Dasyprocta azarae & 0 & 0 & 0 & 0 & 0 & 0 & 0 & 0 & 0 & 0 & 1 \\
\hline Thrichomys pachyurus & 0 & 37 & 1 & 0 & 0 & 0 & 37 & 1 & 0 & 1 & 8 \\
\hline Rhipidomys macrurus & 0 & 0 & 0 & 0 & 0 & 0 & 1 & 0 & 0 & 0 & 1 \\
\hline Oecomys bicolour & 4 & 0 & 1 & 0 & 3 & 3 & 0 & 0 & 2 & 0 & 2 \\
\hline Oecomys roberti & 2 & 0 & 0 & 0 & 1 & 2 & 0 & 0 & 1 & 0 & 0 \\
\hline Oligoryzomys sp. & 0 & 5 & 0 & 0 & 0 & 0 & 1 & 0 & 0 & 0 & 0 \\
\hline Proechimys aff. longicaudatus & 2 & 0 & 6 & 0 & 3 & 6 & 0 & 3 & 2 & 0 & 1 \\
\hline Kunsia tomentosus & 0 & 0 & 0 & 2 & 0 & 0 & 0 & 1 & 0 & 0 & 0 \\
\hline Necromys lasiurus & 0 & 0 & 0 & 6 & 0 & 0 & 0 & 0 & 0 & 0 & 0 \\
\hline Euryzygomatomys spinosus & 0 & 0 & 0 & 2 & 0 & 0 & 0 & 0 & 0 & 1 & 0 \\
\hline Cerradomys maracajuensis & 0 & 2 & 0 & 5 & 0 & 0 & 0 & 0 & 0 & 3 & 0 \\
\hline Calomys sp. & 0 & 0 & 0 & 1 & 3 & 0 & 1 & 1 & 0 & 0 & 0 \\
\hline \multicolumn{12}{|l|}{ Marsupialia } \\
\hline Metachirus nudicaudatus & 0 & 0 & 3 & 0 & 0 & 0 & 0 & 0 & 0 & 0 & 0 \\
\hline Didelphis albiventris & 0 & 0 & 0 & 0 & 0 & 0 & 0 & 1 & 0 & 0 & 0 \\
\hline Monodelphis domestica & 0 & 10 & 0 & 0 & 0 & 0 & 7 & 0 & 0 & 0 & 0 \\
\hline Marmosa demerarae & 0 & 0 & 4 & 0 & 0 & 1 & 0 & 0 & 1 & 0 & 0 \\
\hline Marmosops noctivagus & 0 & 0 & 6 & 0 & 0 & 1 & 0 & 0 & 0 & 0 & 0 \\
\hline Caluromys philander & 0 & 0 & 1 & 0 & 0 & 0 & 0 & 0 & 0 & 0 & 0 \\
\hline Marmosa murina & 2 & 0 & 10 & 0 & 1 & 0 & 0 & 0 & 1 & 0 & 0 \\
\hline Didelphis marsupialis & 1 & 0 & 0 & 0 & 0 & 1 & 0 & 0 & 0 & 0 & 0 \\
\hline
\end{tabular}

GF - Gallery Forest, PF - Palm Forest, CE - Cerrado sensu stricto and RF - Rocky Field. 
Table 2. Field number of Small mammal captured with traps during dry and wet season, in Serra das Araras Ecological Station, Mato Grosso.

\begin{tabular}{|c|c|}
\hline Rodentia & Field number (MSF = Manoel dos Santos Filho) \\
\hline Hylaeamys megacephalus & MSF 206 \\
\hline Dasyprocta azarae & MSF 210 \\
\hline Thrichomys pachyurus & $\begin{array}{l}\text { MSF 54, 58, 59, 60, 62, 63, 65, 68, 69, 70, 76, 77, 78, 80, 110, 170, 171, 172, } \\
173,174,176,178,179,181,182,189,191,193,202,205,207,208,209,211 \\
212,213,215\end{array}$ \\
\hline Rhipidomys macrurus & MSF 216, 190 \\
\hline Oecomys bicolor & MSF 49, 218, 161, 217, 52, 160, 157, 46, 105, 162, 222 \\
\hline Oecomys roberti & $\begin{array}{l}\text { MSF 48, 50, 44, 216, 142, 140, 148, 147, 47, 164, 223, 190, 225, 152, 160, } 161 \text {, } \\
164,105\end{array}$ \\
\hline Oligoryzomys sp. & $\operatorname{MSF} 73,75,79,87,88,79,75,87,183,88,73$ \\
\hline Proechimys aff. longicaudatus & $\begin{array}{l}\text { MSF } 42,45,94,95,98,103,104,109,146,149,150,151,153,154,155,158, \\
195,196,198,214,219,143,221\end{array}$ \\
\hline Kunsia tomentosus & MSF $123,124,199$ \\
\hline Necromys lasiurus & MSF $139,141,144,156,169,186,187,194$ \\
\hline Euryzygomatomys spinosus & MSF $132,204,137$ \\
\hline Cerradomys maracajuensis & MSF $82,83,122,127,128,129,135,201,200,203$ \\
\hline Calomys sp. & MSF $126,130,131,133,134,138$ \\
\hline \multicolumn{2}{|l|}{ Marsupialia } \\
\hline Metachirus nudicaudatus & MSF 90, 100, 102 \\
\hline Didelphis albiventris & MSF 197 \\
\hline Monodelphis domestica & MSF 55, 56, 57, 61, 64, 66, 67, 71, 72, 74, 81, 175, 177, 180, 184, 185, 192, 193 \\
\hline Marmosa demerarae & MSF $96,108,111,113,159,220$ \\
\hline Marmosops noctivagus & MSF $91,92,93,101,115,118,165$ \\
\hline Caluromys philander & MSF 117 \\
\hline Marmosa murina & MSF 47, 51, 97, 99, 106, 107, 112, 114, 116, 119, 120, 121, 145, 220, 224 \\
\hline Didelphis marsupialis & MSF 53, 163 \\
\hline
\end{tabular}

RF. In GF, the first two samplings were conducted in a secondary forest with about 18 years of regeneration, where a sampling effort of 2,400 traps-nights resulted in six species captured, $67 \%$ were rodents. However, in PF $60 \%$ were marsupials, with eight species captured in the first trap-night (Figure 2). The last trap-night in a primary forest of GF, added more four species, with one exclusive species. In open areas, eight and six species were captured, respectively in $\mathrm{CE}$ and $\mathrm{RF}$.

Among the four studied habitats, rarefaction curves reached an asymptote only for captures conducted in PF and CE (Figure 2). The RF had low species richness, with only three residents (Thrichomys pachyurus, Monodelphis domestica and Oligoryzomys sp). Rhipidomys macrurus, Calomys sp. and Cerradomys maracajuensis were captured just in ecotones between RF and other habitats, such as Cerrado sensu stricto, open grassland and gallery forests.

The total small mammal richness was higher in forested areas, when compared to open areas. Independently, samples varied between four and eight species in PF, four and six species in GF, three and five species in CE and four and five species in RF. The total species richness, including rodents and marsupials were not significantly different between habitats (ANOVA; $\mathrm{F}_{3,7}=0,505, \mathrm{P}=0,691$ )
(Figure 3). The richness of rodents was higher in GF, ranging from two to six species, followed by CE, (3-5), RF (3-4), and PF (2-3). These variations, however, were not significantly different between habitats (ANOVA; $\mathrm{F}_{3,7}=0,929, \mathrm{P}=0,475$ ) (Figure 4a).

The wider range of marsupials richness was observed in $\mathrm{PF}$, between two and five species followed by GF (0-2), CE (0-1) and RF (1 species in each sampling area). Regarding marsupials, $\mathrm{PF}$ was significantly richer than the other habitats studied (ANOVA; $\mathrm{F}_{3,7}=4,898, \mathrm{P}=0,038$ ) (Figure 4b).

Similarity among studied habitats was verified by cluster analysis, and two groups were identified (Figure 5): forested areas and open areas. The secondary forests in GF (GF1 and GF2) and in PF (PF3) were grouped; four species were recorded in these three sites (Marmosa murina, Oecomys bicolor, Oecomys roberti and Proechimys aff. longicaudatus). PF1 and PF2 had five species in common: Oecomys bicolor, Oecomys roberti, Proechimys aff. longicaudatus, Marmosa demerarae and Marmosops noctivagus; the last one is restricted to these two sites. GF3 was the most different site from all forested habitats, with two species occurring exclusively there (Hylaeamys megacephalus and Dasyprocta azarae). Cluster of forested 


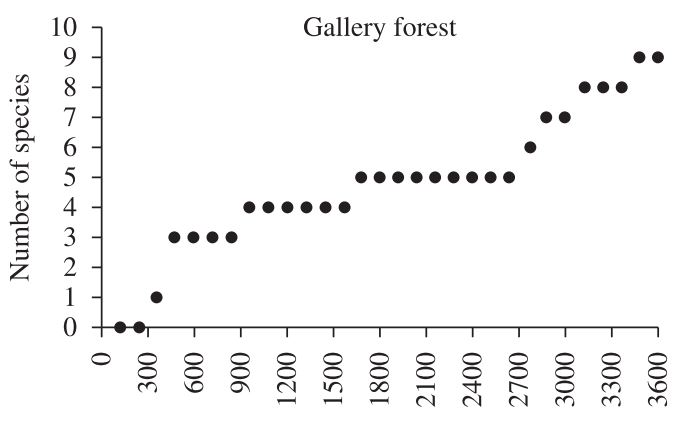

Traps x night

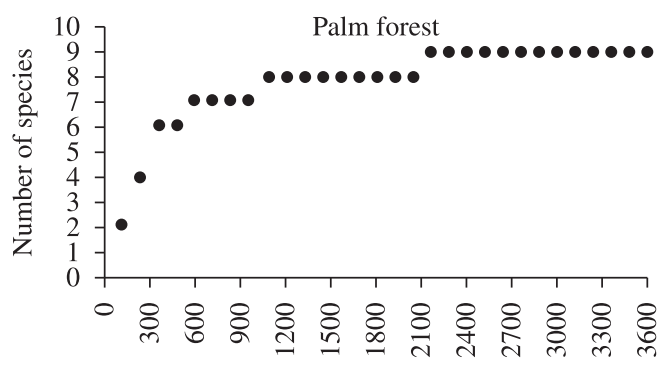

Traps x night

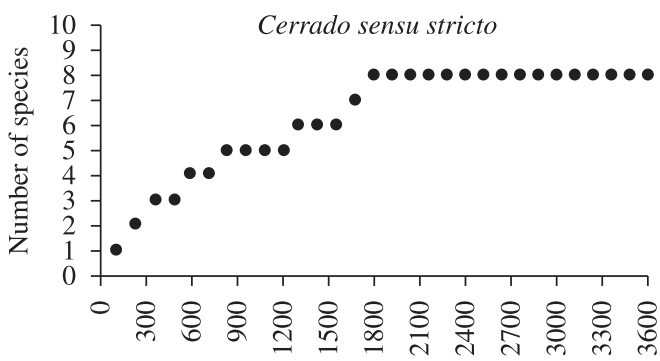

Traps x night

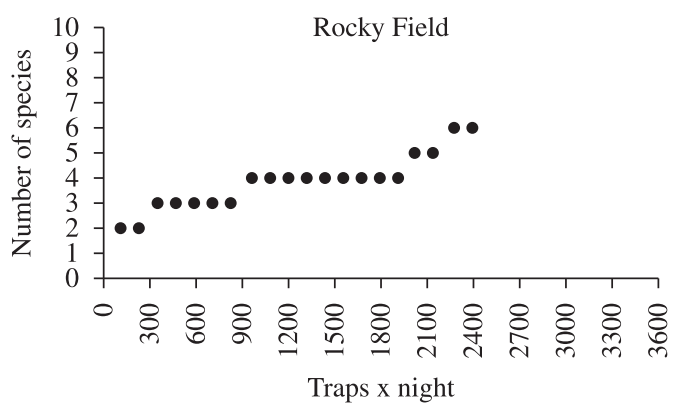

Figure 2. Cumulative curve of number of small mammals captured in traps in four studied habitats in Serra das Araras Ecological Station.

areas were reinforced by the presence of exclusive species to this habitat, such as: Marmosa demerarae, Marmosops noctivagus, Hylaeamys megacephalus, Dasyprocta azarae, Metachirus nudicaudatus, Didelphis marsupialis and Caluromys philander. Another three species (Oecomys bicolor, Oecomys roberti and Proechimys aff. longicaudatus) were also more commonly captured in forested areas.

The cluster of open areas was formed due to the presence of species such as Thrichomys pachyurus, Cerradomys maracajuensis and Calomys sp. (Figure 5).

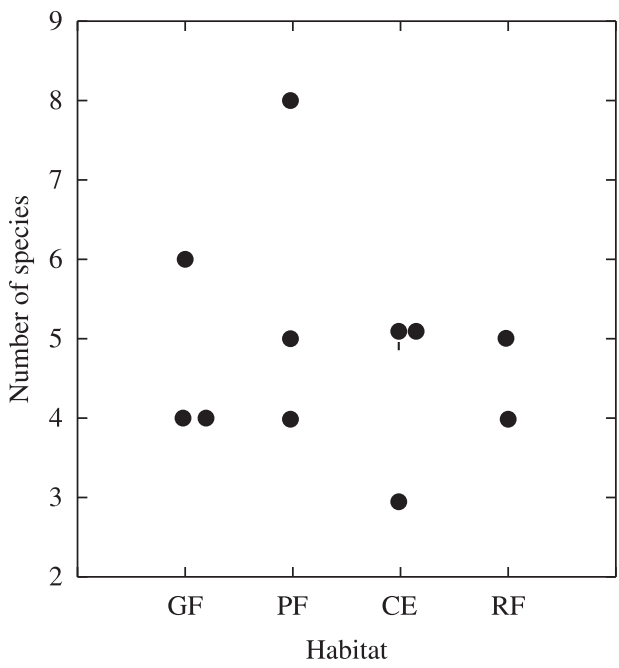

Figure 3. Species richness in Gallery Forest (GF), Palm Forest (PF), Cerrado sensu stricto (CE) and Rocky Field (RF) in Serra das Araras Ecological Station, Mato Grosso. Total species richness of small mammals, captured in traps in four focal habitats.

\subsection{Small mammals' species composition}

From 21 species recorded, 12 occurred exclusively in one habitat (Figure 6). Hylaeamys megacephalus and Dasyprocta azarae only occurred in GF, representing $22.22 \%$ of the total species in this habitat. In Serra das Araras, Dasyprocta azarae was frequently observed in GF, $\mathrm{PF}$, and sometimes at the edge of CE. In PF1, D. azarae fur was found inside a tomahawk, but the size of traps restrained the capture of adult individuals. In Serra das Araras, from 23 captures of Proechimys aff. longicaudatus, three occurred in Cerrado sensu stricto.

In PF, Caluromys philander, Metachirus nudicaudatus, Marmosa demerarae and Marmosops noctivagus, were restricted to this area, representing $44.44 \%$ of the total of species captured in this habitat. In CE, Necromys lasiurus, Euryzygomatomys spinosus, Kunsia tomentosus and Didelphis albiventris, were restricted to this habitat, representing $50 \%$ of the total of captures in this habitat. Necromys lasiurus was the most common species captured during the study, but only occurred in open areas.

Monodelphis domestica and Oligoryzomys sp were restricted to RF, representing $33.33 \%$ total of captures in this habitat. Thrichomys pachyurus was very abundant in this habitat (Table 1), but it was captured in all studied habitats (Figure 6).

All four habitats were assessed using Hybrid MultiDimensional Scaling (HMDS) Analysis. The matrix of small mammals' abundance based on capture data was reduced to two dimensions (axis). The ordination analysis of total species composition showed distinct clusters only in open areas, denoting similarity between the use of forested habitats (PF and GF), and differences between forested habitats and $\mathrm{CE}$ and RF (Figure 7). 

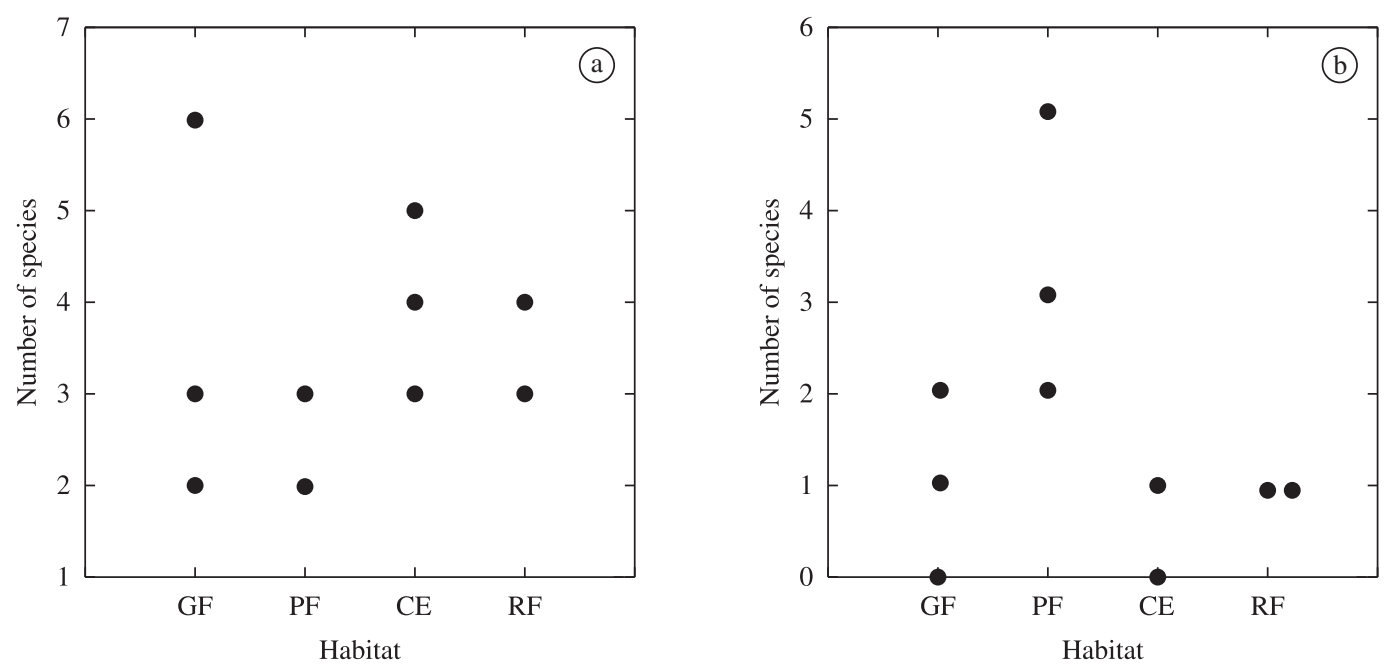

Figure 4. Species richness in Gallery Forest (GF), Palm Forest (PF), Cerrado sensu stricto (CE) and Rocky Field (RF) in Serra das Araras Ecological Station, Mato Grosso a) rodent richness b) marsupials richness.

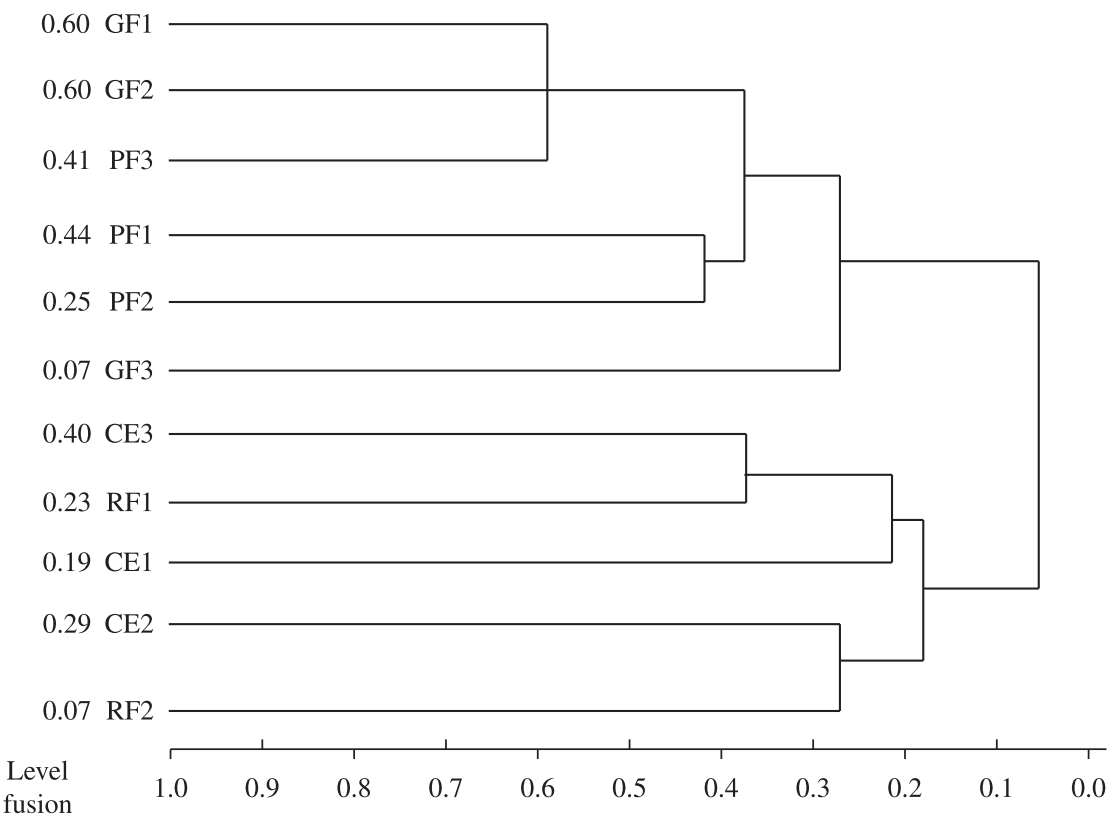

Figure 5. Dendrogram based on cluster analyses UPGMA and Jaccard coefficient, for communities of small mammals, in four habitats in Serra das Araras Ecological Station. GF - Gallery Forest, PF - Palm Forest, CE - Cerrado sensu stricto e RF - Rocky Field.

The ordination analyses for marsupials (Figure 8a) showed an isolated cluster for RF and a stronger similarity between forested areas when compared to open areas. These results suggest differences in the use of habitat. For rodents (Figure 8b), the ordination analyses showed a trend of clusters separating forested areas from open areas, however there is a greater overlapping of groups than the pattern observed for marsupials.

\subsection{Small mammals abundance}

To analyse the degree of similarity among studied habitats, using small mammals abundance data, we used Bray-Curtis coefficient with the clustering method (UPGMA). The analysis presented has no cluster pattern among the studied habitats.

Among all areas, only RF, with three common species, had a distinct specific abundance. Two of these species 
Species Gallery forest Palm fores Cerrado sensu stricto Rock field

Hylaeamys megacephalus Dasyprocta azarae Didelphis marsupialis

Marmosa murina

Oecomys bicolour

Oecomys roberti

Proechimys aff. longicaudatus Caluromys philander

Metachirus nudicaudatus

Marmosa demerarae

Marmosops noctivagus

Kunsia tomentosus

Necromys lasiurus

Euryzygomatomys spinosus

Didelphis albiventris

Cerradomys maracajuensis

Thrichomys pachyurus

Calomys sp.

Rhipidomys macrurus

Monodelphis domestica

Oligoryzomys sp.

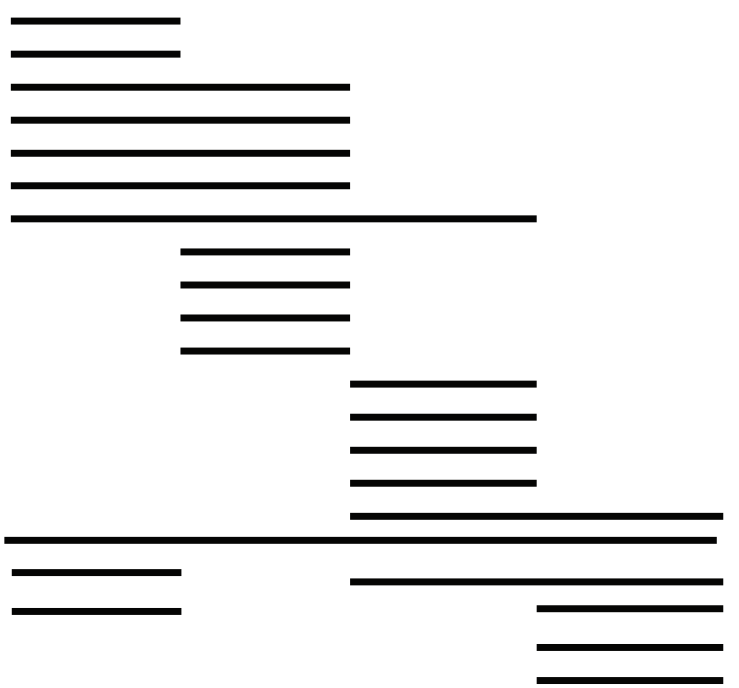

Figure 6. Use of habitat for small mammals in Serra das Araras Ecological Station; Lines represent the presence of each species in each habitat.

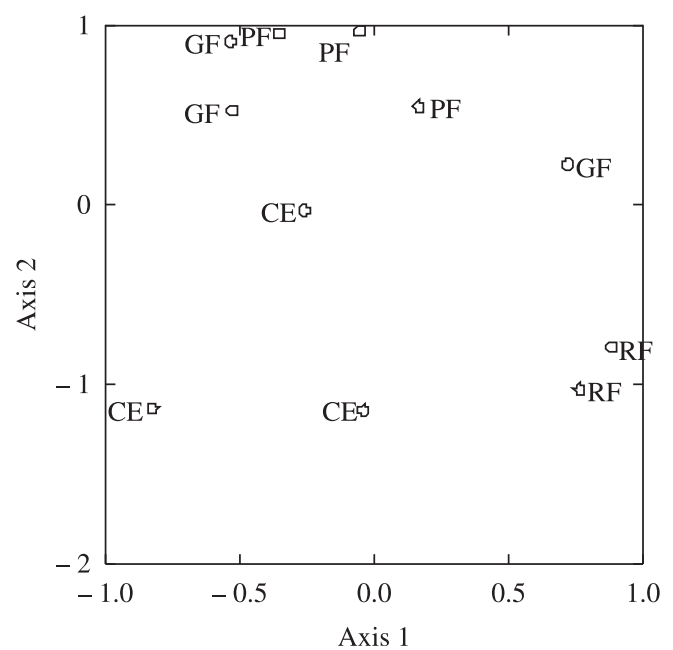

Figure 7. Hybrid Multi-dimensional Scaling (HMDS) based on the total number of small mammals captured in each habitat in Serra das Araras Ecological Station, Mato Grosso. GF - Gallery Forest, PF - Palm Forest, CE - Cerrado sensu stricto and RF - Rock Field.

(Thrichomys pachyurus and Monodelphis domestica) are very common in that area (Figure 9 and Table 1). This habitat formed an isolated cluster, with its own characteristics, very homogeneous landscape and microhabitat structure. This habitat presented low richness of small mammals, but with high abundance of T. apereoides and M. domestica.

The second cluster consisted of CE1 and CE3 due to the presence of two common species in these sites, Cerradomys maracajuensis and Euryzygomatomys spinosus, presenting similar abundances (Figure 9 e Table 1).

\subsection{Seasonality}

During six months of dry season between May and October, sampling with traps resulted in 16 species captured, representing $80 \%$ of the total diversity recorded for the entire study. Between November and January (wet season), 15 species were captured, representing $75 \%$ of the total. Five species $(25 \%)$ were recorded only during the dry season (Didelphis marsupialis, Caluromys philander, Metachirus nudicaudatus, Marmosops noctivagus and Necromys lasiurus) and four (20\%) only in the wet season (Hylaeamys megacephalus, Dasyprocta azarae, Didelphis albiventris and Rhipidomys macrurus) (Table 1).

Regardless of that, the sampling effort during the dry season was two-fold the effort during the wet season (six and three months, respectively), the difference in species richness between the two seasons was only 5\% (Table 1). However, the small mammal abundance was high during the dry season and low during the wet season (Table 1).

In Serra das Araras Ecological Station, marsupial species richness and abundance were greater during the dry season, mainly in July, when five species were captured; two of these species were captured only in this month.

\section{Discussion}

Forested areas had the same richness when compared to open areas. Moreover, the more preserved forest had higher species richness, indicating that the higher complexity of the primary forests, represented by vegetation structure, convey important resources such as food, nestling places, shelter and more fundamental ecological niches to individual success to each species, as suggested by Alho (1981) and August (1983). The low species richness found in two 

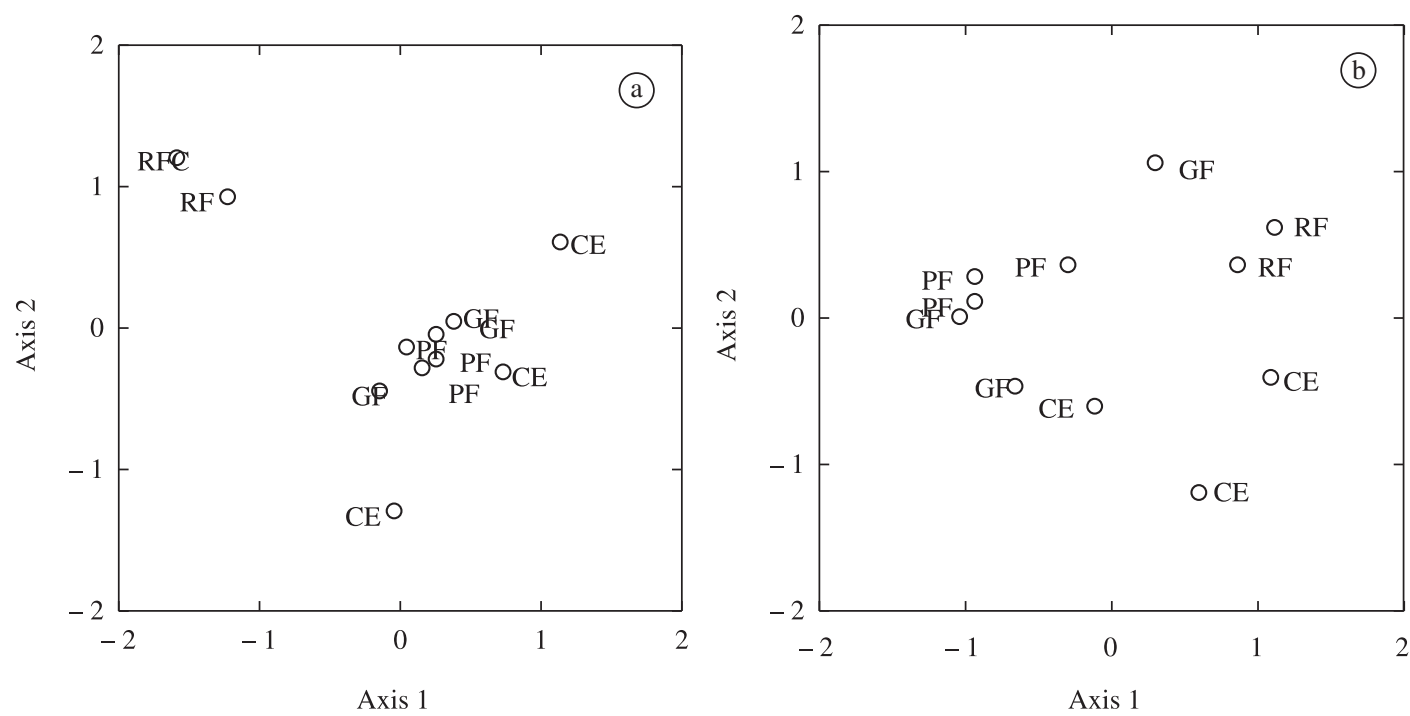

Figure 8. Hybrid Multi-dimensional Scaling (HMDS) based on the total number of small mammals captured in each habitat in Serra das Araras Ecological Station, Mato Grosso. a) marsupials composition. b) rodents composition. GF - Gallery Forest, PF - Palm Forest, CE - Cerrado sensu stricto and RF - Rock Field.

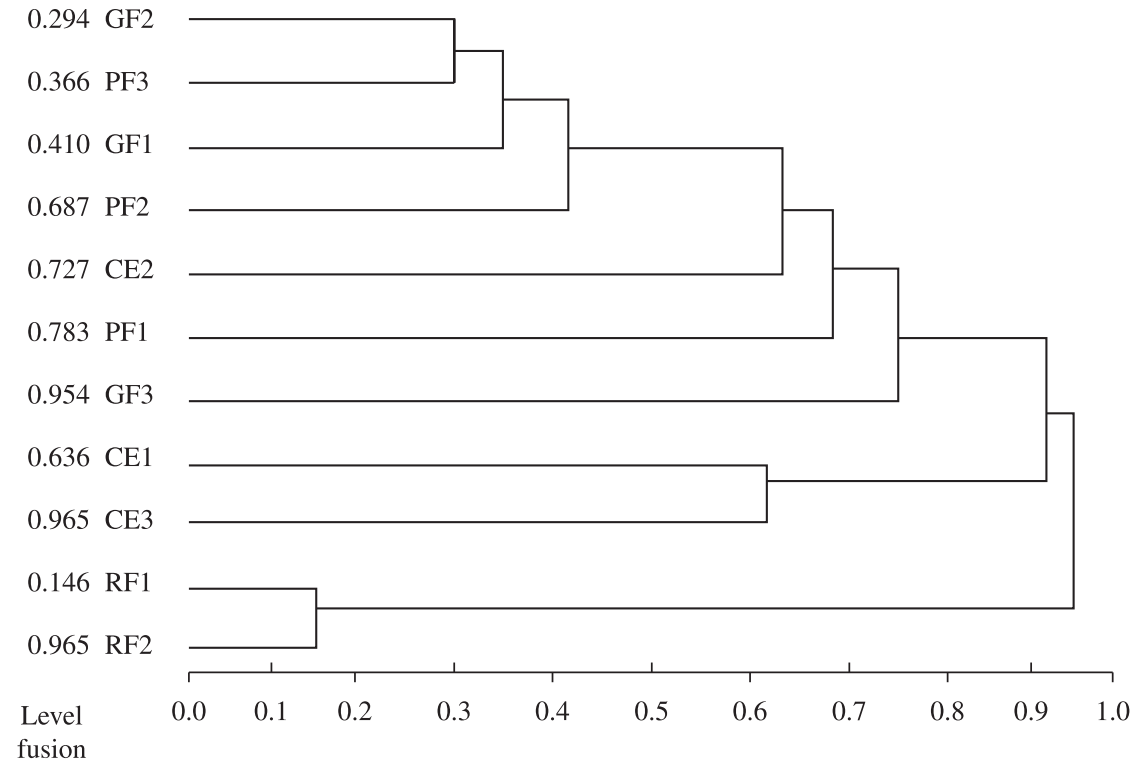

Figure 9. Dendogram using the cluster method (UPGMA) with Bray-Curtis coefficient, to verify the similarity of small mammals communities' abundance, in four habitats studied in Serra das Araras Ecological Station, Mato Grosso. GF - Gallery Forest, PF - Palm Forest, CE - Cerrado sensu stricto and RF - Rock Field.

secondary gallery forests might be related to the low degree of stratification, with vegetation rarely reaching more than 6-m high. Marsupials' high richness in palm forests might be related to the presence of palm leaves yielding good nestling places and shelter. The microhabitat in these places may contribute to the high density of arthropods, which is the main dietary component of most of the marsupials (Pinheiro et al., 2002).
The rarefaction curve for captures in the gallery forest and rocky field did not reach an asymptote; the effort may have not been enough for all the small mammal community. It is worth noting that an exhaustive sampling is not part of the scope of this research, although data presented here suffice for comparisons among habitats.

Low richness and high abundance of resident species in rocky fields could be related to a low complexity of the 
habitat. Low richness and high abundance were observed for small mammals in Amazonian regions with intense climatic seasonality (Malcolm et al 2005). Species from other habitats were captured in the rocky field edges. As they were not captured in more central areas, it is likely that these species have home ranges on marginal areas of this habitat. The use of the habitat edge might be related to search for food or competition avoidance, as suggested by Alho (1981).

The higher richness of resident species in forested habitats may be due to higher complexity in vegetation structure, which is related to biotic and abiotic factors, such as climatic seasonality, temperature variation, and population interactions, influencing species' number and distribution (August, 1983).

Regarding the total species composition of the small mammal community, more than half were restricted to one studied habitat. Following Hansson (1996), some mammals are specialists using only one habitat type. For example, Proechimys occurs in forested areas, such as forests in the Amazon and gallery forests in central Brazil (Alho, 1981; Emmons, 1982). In Serra da Araras, it occurred in Cerrado sensu stricto; two of these captures were $15 \mathrm{~m}$ from gallery forests' edge, and a third capture was more than $250 \mathrm{~m}$ from gallery forests, when Cerrado had a fruiting peak, in December. Proechimys roberti another species from the same genus is also restricted to forested areas in Cerrado in Central Brazil (Planalto Central) (Alho, 1981). According to Alho (1982), this genus is apparently dependent on water sources, as it was not captured in dry and open habitats, but only in gallery forests in Cerrado. In this study, the use of Cerrado sensu stricto by Proechimys aff. longicaudatus could be explained by changes in resources distribution along the year, as suggested by Emmons (1982).

In EESA, Marmosa demerarae was very abundant in the palm forest, but in the Amazon this species occurred in undisturbed areas of terra firme, secondary forest and areas with seasonal floods (Patton et al., 2000; Malcolm et al., 2005), also present in disturbed areas (Tavares, 1998; Pardini, 2001). In forest fragments in southwest Mato Grosso, this species was the second most captured, also occurring in forest fragments' edges, but never in pasture (Santos-Filho et al., 2008b); in the Amazon, however, some individuals were observed crossing short pasturelands (about $300 \mathrm{~m}$ ) surrounded by forest (MNFS, unpublished data). Necromys lasiurus was captured only in Cerrado sensu stricto areas in Cerrado in Alter do Chão (Magnusson et al., 1995), however Ribeiro and Marinho-Filho (2005) captured that species in murundus fields (grassland) in the Brazilian Federal District. In studies conducted by Santos-Filho et al. (2008b), analysing fragmentation effects in southwest Mato Grosso, N. lasiurus and Calomys sp were more abundant in pasture, but there were captures inside forest fragments, demonstrating to be generalists about habitat use.

The spatial distribution of $T$. apereoides is usually associated to the presence of protruding rocks (boulders) where they can find places to shelter and nestle (Alho, 1982; Mares et al., 1989; Nowak, 1991; Lacher and Alho,
1989). In Serra das Araras, all captures of this species was close to rocks. In Brazilian Wetlands (Pantanal), Lacher and Alho (1989) found the same species in grassland, lake banks, Cerrado and deciduous forest. Some species were captured in traps two meters of height on tree branches in gallery forests. According to Alho (1982), T. apereoides is scansorial and a good climber. Rhipidomys macrurus was captured in Rocky Field only once, and at $10 \mathrm{~m}$ from forest edge on the ground, demonstrating that the species might use suboptimal habitats. Rhipidomys spp. are nocturnal, well-adapted to arboreal life and in Cerrado they are known for using gallery forest (Alho, 1982; Mares et al., 1989), and avoid open habitats.

Regardless of the largest sampling effort during the dry season, there was a small seasonal difference in species richness; abundance, however it was high during the dry season. This may be due to high food abundance during the wet season, which might reduce baits' attractiveness and increase trap avoidance; while the opposite may happen during the dry season. The same seasonal pattern was observed in Venezuela by O'Connell (1989), but it was more intense in open areas than in forests.

\section{Conclusions}

The total number of captured species in this study was high considering the total sampling effort. Two out of four habitats did not reach an asymptote in the rarefaction curve, indicating the need for a larger sampling effort. Among the four sampling habitats, the palm forest was the most marsupial-rich, possibly due to specific microhabitats present in this habitat type. In accordance with our results, to sustain small mammal diversity in Cerrado it is extremely important to support protected areas with heterogeneous environments using the maximum variety of phyto-physiognomies possible, to benefit a number of species that use specific environments and/or prefer to use those habitat types.

\section{References}

ALHO, CJ., PEREIRA, LA. and PAULA, AC., 1986. Patterns of habitat utilization by small mammals population in cerrado biome of Central Brazil. Mammalia, vol. 50, no. 4, p. 447-460. http://dx.doi.org/10.1515/mamm.1986.50.4.447

ALHO, CJR., 1981. Small mammal populations of Brazilian cerrado: the dependence of abundance and diversity on habitat complexity. Revista Brasileira de Biologia = Brazilian Journal of Biology, vol. 41, no. 1, p. 223-230.

-, 1982. Brazilian Rodents: Their Habitats and habits. Special Publication Pymatuning Laboratory of Ecology, no. 6, p. 143-166.

-, 1993. Distribuição da fauna num gradiente de recursos em mosaico. In PINTO, MN. (Ed.). Cerrado: Caracterização, Ocupação e Perspectiva. Brasília: Editora da Universidade de Brasília, Secretaria do Meio Ambiente, Ciência e Tecnologia do Distrito Federal. p. 213-262 
AUGUST, PV., 1983. The role of habitat complexity and heterogeneity in structuring tropical mammal comunities. Ecology, vol. 64, no. 6, p. 1495-1507. http://dx.doi.org/10.2307/1937504

BONVICINO, CR., CERQUEIRA, R. and SOARES, VA., 1996. Habitat use by small mammals of upper Araguaia River. Revista Brasileira de Biologia = Brazilian Journal of Biology, vol. 56, no. 4, p. 761-767.

Brasil. Ministério do Meio Ambiente, dos Recursos Hídricos e da Amazônia legal, 1979. Plano do Sistema de Unidades de Conservação do Brasil. Brasília: Instituto Brasileiro de Desenvolvimento Florestal. 107 p.

Brasil. Ministério do Meio Ambiente, dos Recursos Hídricos e da Amazônia legal. Programa Nacional do Meio Ambiente - PNMA. Plano de Conservação da Bacia do Alto Paraguai - PCBAP, 1997. PCBAP/Projeto Pantanal, Programa Nacional do Meio Ambiente. Brasília: PNMA. vol. 2, tomo 6.

EITEN G., 1972. The Cerrado vegetation of Brazil. Botanical Review, vol. 38, p. 205-341. http://dx.doi.org/10.1007/BF02859158

EMMONS, LH., 1982. Ecology of Proechimys (Rodentia, Echiyidae) in south-eastern Peru. Tropical Ecology, vol. 23, p. 280-290.

FONSECA, GAB. and REDFORD, KH., 1984. The mammals of IBGE Ecological Reserve, Brasília, and an analysis of the role of gallery forests in increasing diversity. Revista Brasileira Biologia = Brazilian Journal of Biology, vol. 44, no. 4, p. 517-523.

HANSSON, L., 1996. Habitat selection or habitat-dependent survival: theory for spatial dynamics of small mammals. OIKOS, vol. 75 , no. 3, p. 539-542. http://dx.doi.org/10.2307/3545897

LACHER, TE. and ALHO, CJR., 1989. Microhabitat use among small mammals in the brazilian Pantanal. Journal of Mammalogy, vol. 70, no. 2, p. 396-401. http://dx.doi.org/10.2307/1381526

LACHER, TE. and ALHO, CJR., 2001. Terrestrial small mammal richness and habitat associtions in an Amazon Forest-Cerrado contact zone. Biotropica, vol. 33, no. 1, p. 171-181.

LACHER, TE., MARES, MA. and ALHO, CJR., 1989. The structure of a small mammal community in a Central Brazilian Savanna. Advances in Neotropical Mammalogy, p. 137-162.

MACHADO, RB., RAMOS NETO, MB., PEREIRA, PGP., CALDAS, EF., GONÇALVES, DA., SANTOS, NS., TABOR, K. and STEININGER, M., 2004. Estimativas de perda da área do Cerrado brasileiro. Brasília: Conservação Internacional. Relatório técnico não publicado.

MAGNUSSON, WE., FRANCISCO, AL. and SANAIOTTI, TM., 1995. Home-range size and territoriality in Bolomys lasiurus (Rodentia: Muridae) in an Amazonian savanna. Journal of Tropical Ecology, vol. 11, p. 179-188. http://dx.doi.org/10.1017/ S0266467400008622

MALCOLM, JR., PATTON, JL. and SILVA, MNF. 2005. Small mammal communities in upland and floodplain forests along an Amazonian white-water river. In LACEY, EA. and MYERS, P. (Eds.). Mammalian Diversification: From Chromosomes to Phylogeography (A Celebration of the Career of James L. Patton). University of California Publications in Zoology. vol. 133 , p. $335-380$

MARES, MA., ERNEST, KA. and GETTINGER, DD., 1986. Small mammal community structure and composition in the Cerrado Province of central Brazil. Journal of Tropical Ecology, vol. 2, p. 289-300. http://dx.doi.org/10.1017/S0266467400000948

MARES, MA. and ERNEST, KA., 1995. Population and community ecology of small mammals in a gallery forest of central Brazil.
Journal of Mammalogy, vol. 76, no. 3, p. 750-768. http://dx.doi. org/10.2307/1382745

MARES, MA., BRAUN, JK. and GETTINGER, D., 1989. Observations on the distribution and ecology of the mammals of the Cerrado grasslands of central Brazil. Annals of Carnegie Museum, vol. 58, no. 1, p. 1-60.

NOWAK, RM., 1991. Walker's Mammals of the World. 5th ed. The Johns Hopkins University Press. vol. 2, p. 947-948. http:// dx.doi.org/10.2307/1381425

O'CONNELL, MA., 1989. Population dynamics of Neotropical small mammals in seasonal habitats. Journal of Mammalogy, vol. 70 , no. 3, p. 532-548.

PARDINI, R., 2001. Pequenos mamíferos e a fragmentação da Mata Atlântica de Una, Sul da Bahia - Processos e Conservação. São Paulo: Instituto de Biociências, Universidade de São Paulo. Tese de Doutorado em Ciências.

PATTON, JL., DA SILVA, MNF. and MALCOLM, JR., 2000. Mammals of the rio Juruá and the Evolutionary and Ecological Diversification of Amazônia. Bulletin of the American Museum of Natural History, no. 244, 306 p.

PINE, RH., BISHOP, IR. and JACKSON, RL., 1970. Preliminary list of mammals of the Xavantina/Cachimbo Expedition (Central Brazil). Transactions of the Royal Society of the Tropical Medicine and Hygiene, vol. 64, no. 5, p. 668-670. http://dx.doi.org/10.1016/00359203(70)90003-9

PINHEIRO, PS., CARVALHO, FMV., FERNANDEZ, FAS. and NESSIMIAN, JL., 2002. Diet of the Marsupial Micoureus demerarae in Small Fragments of Atlantic Forest in Southeastern Brazil. Studies on Neotropical Fauna and Environment, vol. 37, no. 3, p. 213-218. http://dx.doi.org/10.1076/snfe.37.3.213.8575

RIBEIRO, R. and MARINHO-FILHO, J., 2005. Estrutura da comunidade de pequenos mamíferos (Mammalia, Rodentia) da Estação Ecológica de Águas Emendadas, Planaltina, Distrito Federal, Brasil. Revista Brasileira de Zoologia, vol. 22, no. 4, p. 898-907. http://dx.doi.org/10.1590/S0101-81752005000400014

SANTOS-FILHO, M., DA SILVA, DJ.and SANAIOTTI, TM., 2008a. Variação sazonal na riqueza e na abundância de pequenos mamíferos, na estrutura da floresta e na disponibilidade de artrópodes em fragmentos florestais no Mato Grosso, Brasil. Biota Neotropica, vol. 8, no. 1, p. 115-121.

SANTOS-FILHO, M., DA SILVA, DJ. and SANAIOTTI, TM., 2008b. Edge effects and landscape matrix use by a small mammal community in fragments of semideciduous submontane forest in Mato Grosso, Brazil. Brazilian Journal of Biology, vol. 68, no. 4, p. 703-710. http://dx.doi.org/10.1590/S151969842008000400004

TAVARES, LNJ., 1998. Efeitos de borda e do crescimento secundário sobre pequenos mamíferos nas florestas de terra firme da Amazônia Central. Manaus: Instituto Nacional de Pesquisas da Amazônia, Universidade Federal do Amazonas. Dissertação de Mestrado em Ciências Biológicas.

VIEIRA, C., 1945. Sobre uma coleção de mamíferos de Mato Grosso. Arquivos de Zoologia, vol. 4, art. 10.

VIEIRA, EM. and PALMA, ART., 2005. Pequenos mamíferos de Cerrado: distribuição dos gêneros e estrutura das comunidades nos diferentes habitats. In SCARIOT, A., FELFILI, JM. and SOUSA-SILVA, JC. (Org.). Cerrado: Ecologia, Biodiversidade e Conservação. Brasília: Ministério do Meio Ambiente. p. 265-282. 